\section{Do human resources policies and practices produce resilient public servants? Evidence of the validity of a structural model and measurement models}

\author{
Ana Carolina Costa ${ }^{1}$ \\ Gisela Demo' \\ ${ }^{1}$ University of Brasilia, Faculty of Economics, Management, Accounting and Public \\ Policy Management, Brasilia, Brazil \\ Tatiane Paschoal ${ }^{2}$ \\ ${ }^{2}$ University of Brasilia, Department of Management, Brasilia, Brazil
}

\begin{abstract}
Purpose - Based on the relevance of resilience in the workplace and the importance of effective human resource management strategies in organizations, this research proposes to identify the influence of human resource management policies and practices on public servant resilience at work.
\end{abstract}

Design/methodology/approach - The data from this quantitative study were analyzed by means of confirmatory factor analysis and regression analysis using structural equation modeling. The data collection was carried out through a survey.

Findings - Involvement policy was the only predictor of resilience at work. In addition, the results revealed two scales (HRPPS and Resilience at Work Scale) with validity and reliability, which can be used in relational scientific studies.

Originality/value - This research contributes to empirical studies in the area of organizational behavior regarding the background investigation of resilience at work and especially the analysis of a relationship between variables not yet explored in the literature.

Keywords - Human Resource Management Policies and Practices; Resilience at Work; Confirmatory Scale Validation; Structural Equation Modeling.
Received on:

$10 / 11 / 2017$

Approved on:

$05 / 23 / 2018$

Responsible Editor:

Prof ${ }^{a}$. Dra. Gina Gaio Santos

Evaluation process:

Double Blind Review

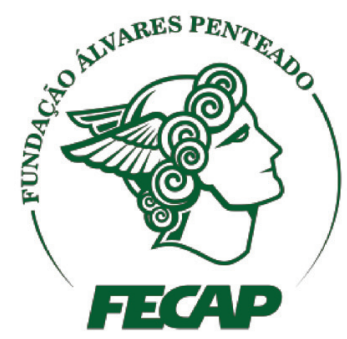

Review of Business Management 


\section{Introduction}

Considering that people are the main protagonists in achieving organizational results and those responsible for knowledge production, human resource management (HRM) policies are important when they are aligned with the organization's goals, providing the conditions for employees to effectively contribute to the achievement of superior results (Armstrong, 2014; Bohlander \& Snell, 2009; Boudreau \& Lawler, 2014; Deadrick \& Stone, 2014; Demo, Martins, \& Roure, 2013; Legge, 1995). In this sense, HRM policies and practices are useful for building productive systems by furthering better results, as well as enhancing employee integration, involvement, and development (Mascarenhas \& Kirschbaum, 2008). Thus, under the strategic HRM approach, policies and practices in line with organizational strategies are fundamental to achieving organizational objectives (Morris \& Snell, 2010).

HRM policies and practices are especially important when considering the demands of the current working world imposed on employees. An employee is expected to be flexible, adaptable to changes, and constantly able to shape themselves to new demands - in other words, a resilient employee (Ribeiro, Mattos, Antonelli, Canêo, \& Goulart, 2011). Resilience is considered to be a process that allows people to face adversities through the interaction of social and intrapsychic aspects (the characteristics and capacities of each person) with their surroundings (Yunes, 2003). Thus, the term "resilience at work" relates to the individual's capacity to resignify adverse situations in the organizational context (Gomide, Silvestrin, \& Oliveira, 2015).

In the academic field, the study of resilience seeks to contribute to the understanding of personal strengths, which should favor the potentialities of individuals, making them stronger and more productive (Ryff \& Singer, 2003). In the field of management, it is possible to raise the question: can organizational variables influence worker resilience?
Therefore, based on the relevance of resilience to work and the importance of effective HRM strategies in organizations, this research aimed to identify and describe the influence of human resource management policies and practices on the resilience at work of the University of Brasília Foundation's (FUB) technical-administrative public servants. In order to achieve this objective, the structural predictive model connecting HRM policies and practices to resilience at work was tested, and, through testing its measurement model, both the Human Resource Policies and Practices Scale (Demo, Neiva, Nunes, \& Rozzett, 2014) and the Resilience at Work Scale (Gomide et al., 2015) were confirmed. This study sought to fill the gap in the literature regarding the relationship between human resource management policies and practices and resilience at work, theoretically advancing the identification of consequences of HRM policies and practices. It also makes a contribution due to the innovative type of research in the public sector since the majority of related studies of human resource management policies and practices and resilience at work concern the private sector.

\section{Literature Review}

\section{I Human resource management policies and practices}

HRM can be defined as a strategic, integrated, and coherent approach to the employment, development, and well-being of people in organizations (Armstrong, 2014). In the view of Bohlander and Snell (2009), HRM is the process of managing human talents to achieve the organization's goals.

In this study, policies are understood as articulated proposals of the organization regarding human relations, aiming to achieve the desired results, functioning as thought and action guides for the HRM area (Demo, Nunes, Mendes, Ferreira, \& Melo, 2011). HRM practices are understood as routines and organizational actions 
that operationalize HRM policies (Demo et al., 2014; Legge, 1995).

Whereas HRM professionals provide high-performance development and a competent workforce in organizations (Inyang \& Akaegbu, 2014), it is important to empirically know the results of HRM policies and practices as evidenced by relational scientific studies, which have been growing in recent years, demonstrating an increase in the importance of HRM policies and practices for organizations (Horta, Demo, \& Roure, 2012).

In this context, several studies have shown that HRM policies influence variables such as well-being at work (Horta et al., 2012; Raykov \& Demo, 2014) and confidence in organizations (Horta et al., 2012). In addition, Majumder (2012) and Nannetti, Mesquita, and Teixeira (2015) verified a strong relationship between HRM practices and employee satisfaction.

The studies of Gomide and Tanabe (2012), Guest and Conway (2011), and Kim and Lee (2012) have evidenced the association between HRM policies and practices and greater organizational effectiveness. Along the same lines, Leite, Leite, and Albuquerque (2013) indicated that HRM policies and practices are advantageous and effective for the company. The study by Badejo (2015), in turn, highlighted the influence of HRM policies and practices on employee career development.

Based on the results of these empirical studies, it is possible to affirm that a set of HRM policies and practices, coordinated with organizational strategy, cause a positive impact on the behaviors and attitudes of the employees and in the organization itself, whether public or private. Thus, success in implementing organizational goals depends heavily on how well the organization develops its HRM cycle, selecting the right people, evaluating their performance, and developing the skills necessary to warrant the success of their business strategies (Devanna, Fombrun, \& Tichy, 1984), in order to provide employees with the satisfaction of objective conditions at work, such as income and job stability, and subjective conditions, such as safety, affection, support, and social recognition (Ribeiro et al., 2011).

\subsection{Resilience at work}

With regard to understanding the resilience process in organizational contexts, it is important to highlight risk and protection factors (Ribeiro et al., 2011). Risk factors include stresses from multiple stressful events, such as pressure and responsibility for work, lack of time for the family, lack of support from peers or superiors, little freedom for creation, lack of autonomy in activities, fear of losing one's job, and bullying (Job, 2003b). Protection factors, according to the author, can be considered as reducing the negative influences of accepting risk and seeking adaptive and creative ways of facing difficulties, such as autonomy, self-esteem, respect, recognition, family and friends' participation, and the support of peers and superiors, many of which are covered by HRM practices (Demo et al., 2014).

Thus, the functioning and the structure of an organization can have a major impact on the health and well-being of its employees, which in turn has an impact on the effectiveness of the organization as a whole (Hernandez, 2007). According to Job (2003b), with greater autonomy and training, employees feel more valued and motivated, thus increasing their self-esteem and therefore their resilience.

Since empirical research is the main way to verify possibilities of dialogue between different disciplines (Mendes, 2002), it is necessary to know the recent empirical results of relational scientific studies on resilience. Carvalho, Borges, Vikan, and Hjemdal (2011) verified that resilience contributed significantly to explaining the results of the organizational socialization of public servants of two universities.

In addition, Nalin and França (2015) investigated the importance of resilience, socioeconomic satisfaction, retirement time, and welfare planning for retirement. The results revealed resilience and socioeconomic satisfaction 
as the main predictors of well-being in retirement. Moreover, Gomide et al. (2015) tested the power of resilience at work's mediation in the relationship between the variables of satisfaction with the perceived organizational supports and well-being at work. As a result, the proposed model was not confirmed, but the authors identified that satisfaction with the organizational supports is an antecedent of both resilience and well-being in corporate environments, as well as resilience also being a predictor of well-being.

As seen, resilience, both in Brazil and abroad, is studied as a predictive variable, bolstering the relevance of also studying its antecedents, which was the proposal of this research.

\section{Method}

This study was explanatory because it aimed to test the proposed measurement and structural models (Hair, Babin, Money, \& Samouel, 2005). As for the means used to achieve the objective, the survey method was used based on a quantitative approach. The temporal horizon was cross-sectional since the data collection occurred at a single moment of reality.

Studying the relationship between the variables, the research model adopted resilience at work as a criterion or endogenous variable and the following as predictor or exogenous variables: recruitment and selection; involvement; training, development, and education; work conditions; competency-based performance appraisal; and compensation and rewards, which comprise the human resource management policies and practices.

The research locus was the University of Brasilia Foundation. FUB aims to strengthen and support the University of Brasília (UnB), a university institution for research, teaching, and continuation in all fields of knowledge and scientific, technical, and cultural dissemination (Universidade de Brasília [UnB], 2015). The population is composed of about 2,000 technicaladministrative public servants working at the
Darcy Ribeiro campus. The decision was taken not to include the teaching staff in this research due to the fact that the HRM policies and practices for them are different from those for the technical-administrative public servants.

The sample was characterized as nonprobabilistic convenience (adhesion), using online collection (through the internet). Byrne (2009), Hair, Black, Babin, Anderson, and Tatham (2009), and Kline (2011) suggest a minimum of 10 subjects for each variable. Regarding the verification of the prediction between the variables, regression model analysis was used through structural equation modeling (SEM) with the maximum likelihood method (Hoyle, 1995; Raykov \& Marcoulides, 2006; Schumacker \& Lomax, 2004). It is important to select a minimum sample that has statistical power greater than 0.80 (Cohen, 1992) in the case of behavioral sciences. Thus, using the GPower 3.1 program and considering the predictive variable human resource management policies and practices, with 6 predictors and $95 \%$ statistical power, a minimum sample of 146 subjects was obtained.

According to Kline (2011), for simple models with few variables, as in the present study, utilizing regression analysis through SEM, an average sample of between 100 and 200 subjects is the minimum that is recommended. Considering 28 observations and 28 parameters, that is, zero degrees of freedom, it is a recursive model, classified as identified above, and suitable for testing using structural equation modeling with the maximum likelihood criterion (Kline, 2011). Thus, following the recommendations of the literature and considering a safety margin due to the data processing stage, the total sample consisted of 490 participants.

At the beginning of the data processing stage, the frequency distribution analysis was conducted. Next, the listwise procedure was used for missing values analysis. In this stage, 77 losses were recorded due to incomplete questionnaires. Subsequently, the investigation was conducted for the presence of outliers, which was performed 
using the Mahalanobis method (Tabachnick \& Fidell, 2013); it identified 20 outliers. Afterwards, the tolerance values and those related to the variance inflation factor were analyzed, revealing that the data did not present multicollinearity nor singularity problems for the sample studied (Myers, 1990).

Finally, we analyzed the assumptions for the use of multivariate analysis, according to Hair et al. (2009), analyzing normal probability graphs and residue charts in order to verify the normality, linearity, and homoscedasticity of the data, as recommended by Field (2009). All assumptions were confirmed.

Thus, a final sample was composed of 393 participants who conformed to the statistical criteria mentioned above. This sample was used for confirmatory factor analysis and for regression analysis. It should be noted that structural equation modeling was conducted and multivariate normality was also analyzed (Marôco, 2010) using the AMOS software.

The questionnaire-type applied research instrument was composed of three parts, namely two measurement scales, both scientifically validated: the Human Resources Policy and Practice Scale (HRPPS) and the Resilience at Work Scale, as well as the demographic-functional part. The instrument also contained an invitation letter to participate in academic research, guidelines for completing the questionnaire, as well as a consent form. The questionnaire was composed of 53 items.

The HRPPS is an improved and more comprehensive (with more policies) version of the Human Resource Management Policy Perception Scale (HRMPPS), developed and validated by Demo (2008). The first version of the HRPPS, with 6 factors and 40 items, was validated in Brazil by Demo, Neiva, Nunes, and Rozzett (2012). The HRPPS was validated cross-culturally in the United States by Demo and Rozzett (2012) and obtained an even better adjustment in confirmatory validation, with the same number of factors (6) and only 32 items, and is therefore called the reduced version of the HRPPS. The reduced version of the HRPPS was translated by Demo et al. (2014) and was the version used in this research.

The aim of the HRPPS is to measure the employees' perception of the existence of HRM policies and practices in organizations. The reduced version of the scale is composed of 32 items, subdivided into 6 factors, namely recruitment and selection (RS); involvement (INV); training, development, and education (TDE); work conditions (WC); competencybased performance appraisal (CBPA); and compensation and rewards (CR). The instrument makes use of a five-point Likert scale, ranging from 1 (totally disagree) to 5 (totally agree). The HRPPS has an explained variance of $58 \%$, Cronbach's alpha greater than 0.81 , and Jöreskog's rho greater than 0.73 .

Regarding the Resilience at Work Scale, Batista and Oliveira (2012) started from the instrument validated by Batista and Oliveira (2008), which in turn originated from the version of the Resilience Scale previously adapted and validated for Brazilian adolescents by Pesce et al. (2005). In order to identify the presence of resilience in employees, the Resilience at Work Scale (Gomide et al., 2015) has a 15-item uniformer structure. The percentage of variance explained by the Resilience at Work Scale is $33.35 \%$, with a Cronbach's alpha of 0.90.

The relationship between the variables was studied using the analysis of the regression model through structural equation modeling, based on the maximum likelihood criterion, whose main function is the specification and estimation of models of linear relations between variables (Kline, 2011). Thus, structural equation modeling was used to verify the regression of the proposed model, using the AMOS statistical program.

According to Hair et al. (2009) and Kline (2011), structural equation modeling can be characterized by two basic components, namely: the structural model, which consists of a path that relates dependent variables to independent 
variables; and the measurement model, which allowed the researchers to confirm the structure of the Resilience at Work Scale, which had previously been validated only with exploratory analysis, and the structure of HRPPS.

This study of the FUB technicaladministrative workers was authorized with the consent of the Postgraduate Director of the Dean's Office of Research and Post-Graduation, as well as the Magnificent Rector of the University.

\section{Results}

\section{I Confirmatory validation of the human resource management policies and practices scales and the resilience at work scale}

In order to test the variable measurement models, we started with confirmatory factorial analysis through structural equation modeling, using the maximum likelihood estimation method since it is the most commonly used estimation method in SEM and because it is more robust to problems of normality and effective for both small and large samples (Hair et al., 2009).

For the purpose of determining the acceptability of an SEM model, verification of the overall fit of a model to the surveyed sample can be performed by means of an absolute fit indicator using the chi-square test statistic $\left(\chi^{2} / \mathrm{df}\right.$ or NC), the RMSEA (Root Mean Square Error of Approximation) statistic, which best represents how well a model fits a population and not just a sample used for estimation (Kline, 2011), and finally an incremental adjustment indicator, such as the CFI (Comparative Fit Index), which is more insensitive to the complexity of the models and is among the most used indexes (Hair et al., 2009). According to the recommendations of Kline (2011), the parameters are: $\mathrm{NC}<3.0$; CFI $\geq 0.90$; RMSEA $<0.08$.

The final structure of the HRPPS included 30 items. It should be noted that the six-factor factorial solution of the original scale structure, validated in Brazil and the United States (Demo et al., 2014), was maintained, with the exclusion of two items, which presented a satisfactory index $(\mathrm{NC}=2.24, \mathrm{CFI}=0.92, \mathrm{RMSEA}=0.06)$. Such data make it possible to state that the multifactorial structure has a good fit, since all the parameters are within the recommendations of Kline (2011).

In addition, the factorial loads of 26 items of confirmatory validation were above 0.5 , revealing good quality and validity of the scale (Hair et al., 2009). Figure 1 shows the final HRPPS measurement model obtained in the confirmatory factor analysis, with the respective parameters.

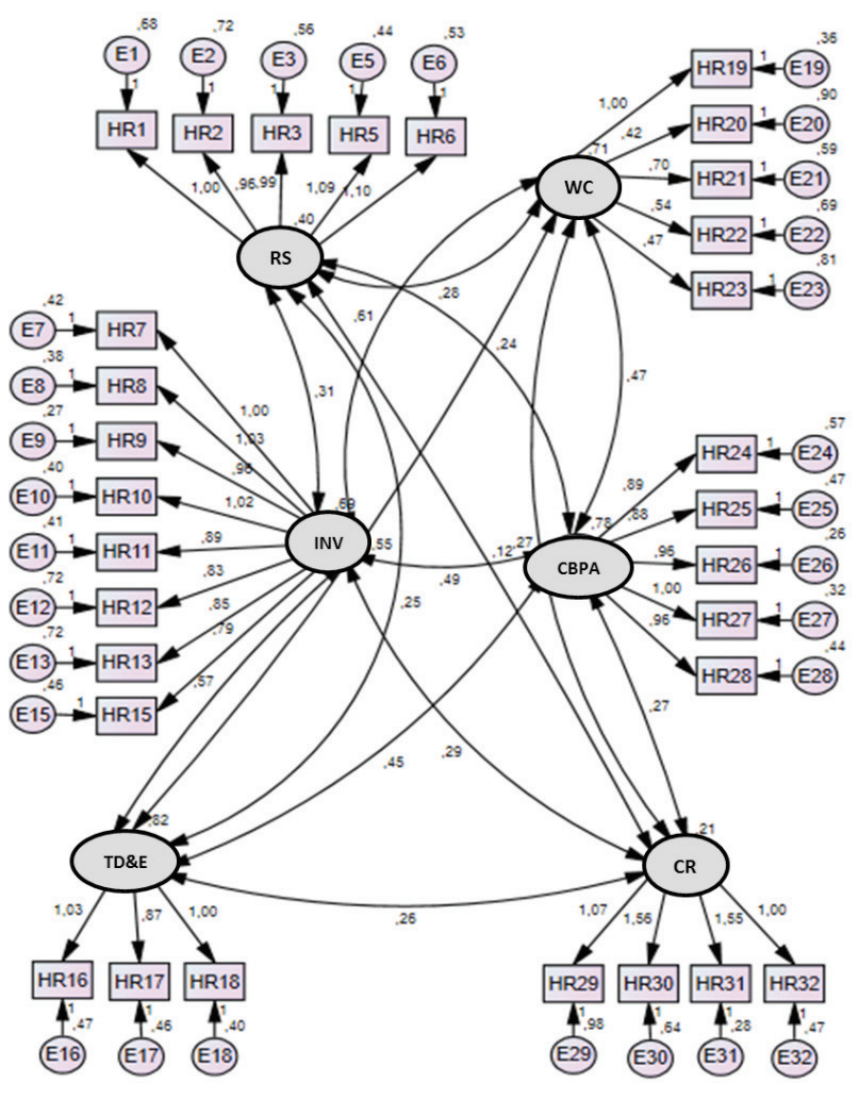

Figure 1. Confirmatory analysis model of HRPPS

Note: $\chi^{2}(390)=872.78 ; \mathrm{p}<0.001 ; \mathrm{NC}=2.24$; CFI $=0.92 ;$ RMSEA $=0.06$

The reliability of the six factors was analyzed by the Jöreskog rho and the values were higher than 0.72. According to Chin (1998), 
these values are considered quite satisfactory, since the Jöreskog indexes should be higher than 0.7.

In summary, the results show that the HRPPS has both internal and external validity (the six-factor structure was tested for a third time with different samples) and also reliability, that is, a reliable operational measure for use in organizational diagnostics and relational studies.

Regarding the Resilience at Work Scale, since confirmatory factor analysis tests to what extent certain variables are representative of a concept/dimension (Figueiredo \& Silva, 2010), six items that presented low loads $(<0.5)$ were removed from the model as they did not contribute to the explanation of the construct in a significant way due to their unsatisfactory adjustment (Hair et al., 2009). Thus, the final structure of the Resilience at Work Scale included 9 items. It is worth noting that the unifactorial solution of the original structure of the scale was maintained.

Therefore, analyzing the indexes of the measurement model of the Resilience at Work Scale $\left(\chi^{2} / \mathrm{df}=3.0\right.$; CFI $=0.96$; $\left.\mathrm{RMSEA}=0.07\right)$, it is possible to state that the scale has a good fit, since all the parameters are in agreement with the recommendations of Kline (2011). The factorial loads of the confirmatory validation items varied between 0.51 and 0.78 , revealing good quality of the items and, therefore, internal validity of the scale (Hair et al., 2009).

Convergent validity refers to the degree of agreement between two or more measures of the same construct (Hair et al., 2009). The psychometric literature presents indicators of convergent validity, such as the composite reliability index (Jöreskog;s rho), which in the case of this scale resulted in 0.86 , indicating appropriate convergence (above 0.7 ). In addition, according to the authors, another attestation of the convergent validity of the scale is when factorial loads are greater than 0.5 , which occurred in all 9 items of the Resilience at Work Scale. With this, it is possible to affirm that the scale showed convergent validity.
In addition, with the intention of improving the adjustment obtained, the modification indexes (MI) were also analyzed, as established by Kline (2011). The MIs between the variables R1 (I am interested in my work) and R7 (My work makes sense to me) and between R7 (My work makes sense to me) and R8 (I am proud to have accomplished things) were high and significant. Thus, a double arrow was introduced between the variables R1 and R7 and between R7 and R8, indicating a positive correlation between the pairs of items, and there is in fact theoretical support for this association.

Based on Morinss (2001) results, work has meaning if it corresponds to the person's interests and competences. In addition, the author affirms that if work is done efficiently, if it leads to something, if it benefits other people, if it allows for learning, accomplishment, and overcoming, and if it allows for expressing and exercising power, this work makes sense. For Hackman and Oldham (1976), work has meaning for a particular person when the person considers it important, useful, and legitimate.

Thus, for Maslow (2001), the path to human happiness is related to the selfrealization achieved through commitment to important and worthwhile work. From a similar perspective, Job (2003a) observed that, regardless of the hierarchical level, everyone identifies work with self-realization, confirming that although the financial factor is relevant, people expect something more from their employment.

Morin (2001) adds that pleasure and a sense of accomplishment can be obtained in the execution of tasks that give meaning to work because work allows for opportunities to overcome challenges or to pursue ideals. Also in this conception, the meaning of work is attributed by the recognition of someone who frequently characterizes the individualıs work as useful (Morin, Tonelli, \& Pliopas, 2007).

Thus, Figure 2 presents the final model for measuring the Resilience at Work Scale obtained from the confirmatory factor analysis with the respective parameters. 


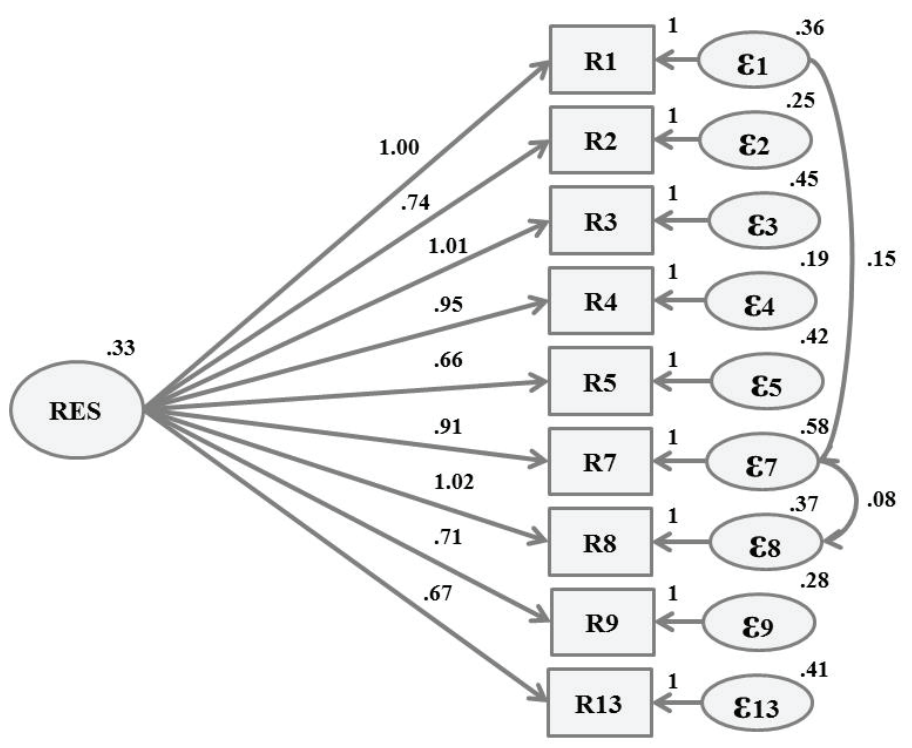

Figure 2. Confirmatory analysis model of the Resilience at Work Scale

Note: $\chi^{2}(25)=75.492 ; \mathrm{p}<0.001 ; \chi^{2} / \mathrm{df}=3.0 ; \mathrm{CFI}=$ $0.96 ;$ RMSEA $=0.07$

The reliability of the single factor structure of the Resilience at Work Scale was analyzed by Jöreskog's rho, which presented $\rho=0.86$, indicating a very satisfactory index (Chin, 1998).

In summary, from the results collected, we can conclude that the Resilience at Work Scale has validity and reliability and can be used in relational scientific studies.

\section{2 Structural model of prediction between human resource management policies and practices and resilience at work}

Firstly, to test the structural model's prediction of resilience at work based on HRM policies and practices, the correlations were studied between all variables, namely the HRM policies and practices represented by the six factors: RS, INV, TDE, WC, CBPA, and CR, and resilience at work (RES).

The correlations found were positive and the involvement factor presented a moderate correlation (from 0.31 to 0.5 ) with resilience at work; the other factors presented a weak correlation (from 0.1 to 0.30 ) with this variable, according to Cohen (1992). However, as all correlations were significant at the $\mathrm{p}<0.01$ level, we started with the prediction analysis between them (Field, 2009).

Thus, to test the structural model of prediction among the variables, regression analysis through structural equations modeling was used with the estimation of maximum likelihood. Regression analysis is preferred over path analysis when testing several independent variables as predictors of a single dependent variable (Hoyle, 1995; Raykov \& Marcoulides, 2006; Schumacker $\&$ Lomax, 2004). Figure 3 illustrates the result of the regression analysis for the proposed model.

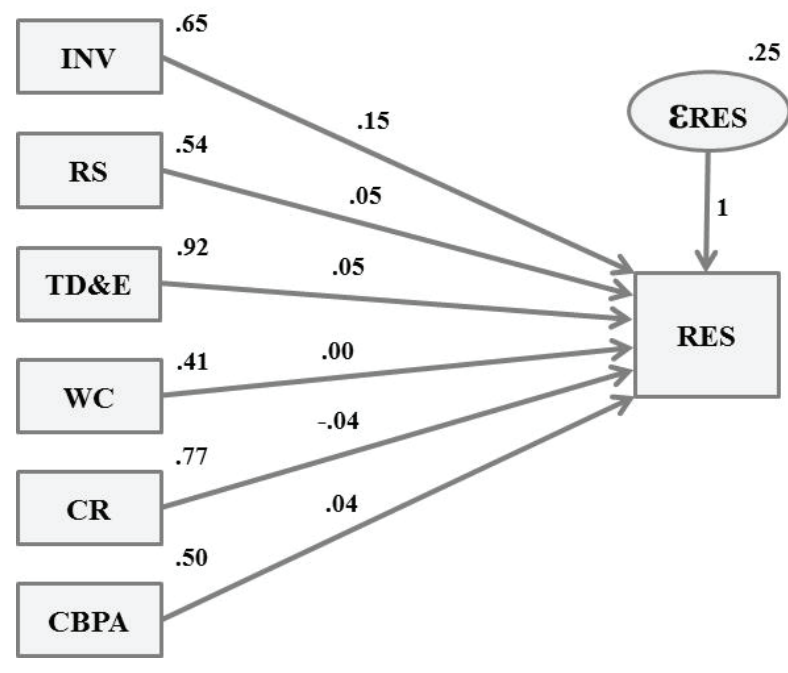

Figure 3. Result of the regression analysis

Among the independent variables tested, the involvement factor was the only predictor of resilience at work. The results of the regression analysis show the amount of resilience at work variance that is explained by the involvement factor $\left(\mathrm{R}^{2}=7.8 \%\right)$, as well as the standardized correlation coefficient $(\beta=0.243)$, which represents the magnitude and the direction of the relationship between the predictor and the criterion-variable; in this case, there is a positive association. In accordance with Cohen (1992), a small effect can be considered since $\mathrm{R}^{2}<13 \%$ and there is also a weak correlation because 0.1 $<\beta<0.30$. 


\section{Discussion}

As pointed out in the literature, HRM policies effectively precede attitudes and behaviors in organizations, as is the case with the organizational-criterion variables organizational commitment (Bastos, 1994; Demo et al., 2013), well-being at work (Horta et al., 2012; Jesus \& Rowe, 2015; Martins \& Demo, 2014), satisfaction at work (Demo et al., 2013; Majumder, 2012; Nannetti, Mesquita, \& Teixeira, 2015; Santos \& Mourão, 2011), and trust in the organization (Horta et al., 2012), besides important organizational results such as performance (Brandão, Borges-Andrade, \& Guimarães, 2012; Freitas \& Borges-Andrade, 2004), organizational turnover (Sheehan, 2013), and organizational effectiveness (Gomide \& Tanabe, 2012; Guest \& Conway, 2011; Kim \& Lee, 2012).

Specifically, involvement policy predicts several attitudes, behaviors, or outcomes, such as organizational commitment (Demo et al., 2013), job satisfaction (Demo et al., 2013), trust in the organization (Horta et al., 2012), and wellbeing at work (Horta et al., 2012; Martins \& Demo, 2014; Sá \& Demo, 2014), which reveals its importance when conceived by the managers of human resource management policies and practices.

The relevance of involvement policy is corroborated by the strong effects it has had on variables such as trust in the organization (27\%), well-being at work (45\%), work commitment (52\%), and job satisfaction (64\%) (Demo et al., 2013; Horta et al., 2012). Resilience at work consists of a complex phenomenon. Both in Brazil and abroad, this phenomenon is studied not only as a diagnosis, but in relational studies as a predictive variable, which bolsters the relevance of also studying its antecedents. Therefore, identifying an organizational context variable as antecedent, even if assessed at the individual level through employees' perceptions and with a small predictive effect, opens up a wide avenue for future research and especially discussions about the role of organizations in the promotion and stimulation of resilience at work.

As this is an exploratory model, the variables of this study were also analyzed from the inverse perspective: with the variable resilience at work predicting HRM policies and practices. As a result, regression indexes were more favorable in the model where resilience at work is a dependent variable. In fact, the interaction of individuals with the context and organizational culture, of which policies and practices are part, can influence them to act in a resilient way (Ribeiro et al., 2011). Thus, for the authors, people use available protection factors and attribute a meaning to adverse situations that allows them to overcome them, so that they experience these adverse conditions without contributing to physical and/ or psychological illness.

It is inferred that involvement practices have more flexibility, and therefore a greater possibility of application in the public sector, such that, from the managerial point of view, they are more feasible for work and possibly because of this, involvement was the only policy that predicted resilience at work. Because it is a public institution, the management of other policies is complex since FUB is an organization that is subject to laws and decrees.

Experiences and behaviors expressed in the organizational context are determined by multiple variables. In the field of psychology and organizational behavior, the explanatory models tested usually address multiple antecedents that combine and interact to determine the dependent variables (Abbad \& Torres, 2002).

Many organizational interventions with employees' behaviors and well-being focus exclusively on the employees themselves; it is the only adjustment variable (Ferreira, 2016). Actions that involve context variables, such as HRM policies and practices, which pervade the entire management of the organization, are usually excluded. This trend can be observed for resilience at work. Managers' and consultants' 
discourse tends to emphasize the importance of employees being resilient and developing such capacity (Anonymous, n.d.). Organizations, in turn, should map out actions and provide support to enable the improvement and expression of resilience.

Based on the results of this study, it can be argued that resilience is a result of protection factors (Job, 2003b; Pesce, Assis, Santos, \& Oliveira, 2004). According to Job (2003b), protection factors can be considered as reducers of negative influences and also as adaptive forms of facing a difficulty, in which autonomy, self-esteem, respect, recognition, family and friends' participation, and the support of peers and superiors can be cited. These ways of facing adversities are contemplated in HRM practices related to employee involvement policy, namely, participation, communication, recognition, and relationship (Demo et al., 2014).

In addition, for Siqueira and Gomide (2008), social support at work is an important factor for the protection and promotion of health and well-being. Similarly, for Batista (2010), it is assumed that the perception of organizational support attenuates vulnerability and risk, reducing the individual's exposure to stressors and adversities since the organization promotes a return on the efforts made by its collaborators, while at the same time providing a more welcoming environment for employees, as it is concerned with their well-being.

Thus, the absence of social support is indicated as a risk factor and its presence as a protection factor (Pinheiro, 2004; Sapienza \& Pedromônico, 2005). From this perspective, social support or a supportive context is a facilitator for the resilience process (Luthar, Cicchetti, \& Becker, 2000). In the same way, protection factors help to reduce the impact of risk and negative reactions and, as such, are predictive of resilience (Pesce et al., 2004).

Organizational managers, in an effort to encourage resilience in their employees, should pay special attention to the planning and implementation of engagement practices, whether by encouraging participation or enhancing communication, practicing continuous feedback, providing respectful treatment, worrying about the well-being of their collaborators, maintaining a climate of understanding and trust between subordinates and colleagues, integrating employees, adapting employees to their positions, giving autonomy in the accomplishment of tasks and in decision making, maintaining coherence between management discourse and practice, and emphasizing the construction of interpersonal relationships that translate into a better organizational climate (Bohlander \& Snell, 2009; Dessler, 2002; Dietz, Wilkinson, \& Redman, 2010; Muckinsky, 2004; Siqueira, 2008; Sisson, 1994; Ulrich; Halbrook, Meder, Stuchlik, \& Thorpe, 1991).

Regarding the limitations and recommendations for future research, this study consists of a first step in proposing and investigating new relationships among variables, contributing, even if only initially, to research on organizational behavior by merging variables from the area of management (HRM policies and practices) and organizational psychology (resilience at work).

In this sense, multi-method studies, incorporating qualitative analyses, are important and necessary to augment the understanding of the relationship between the constructs since they enable the promoted methodological triangulation, allowing for a better understanding of the phenomenon, at the same time that efforts to understand it or measure it are engendered. This is especially important for phenomena that are currently being studied, as is the case with resilience at work, especially in Brazil. Models that test interaction effects between perceived contextual variables and personal variables can also contribute to theoretical advances in the area.

Comparative studies of other university settings are also welcome in order to verify if the structure currently obtained for the Resilience at Work Scale is confirmed for another sample of 
a similar nature. Also, because it was conducted in a single institution, factors related to the organizational culture may have generated biases in the interpretation of the items in the scales used, so that the results generated only apply to the context of the public foundation studied.

\section{Conclusion}

Despite the limitations presented, this study allowed for the established objectives to be achieved, addressing aspects relevant to HRM literature, as well as positive psychology regarding the possible relationship between HRM policies and practices and resilience at work. As a result, it was shown that involvement policy was a predictor of resilience at work, providing a small but significant explanation for the latter. Regarding the confirmatory validation of the Resilience at Work Scale, with one factor, the instrument had a better fit with 9 items and also with the introduction of a double arrow between two pairs of items, indicating a positive correlation between them.

From its theoretical review to the presentation of results, this research contributed to the studies in the areas of HRM and organizational psychology, filling in a gap identified in the literature, since no studies were found that explore the relationship between the perception of policies and practices and resilience at work.

Moreover, it addressed important issues for business management, contributing to the still incipient literature on this subject, especially in the case of resilience in the workplace. In this sense, this study also contributed academically to the study of involvement at work, considering that research related to this policy represents only $2 \%$ of the HRM literature, and the analyses focused solely on communication practice (Demo, Fogaça, Fernandes, \& Sá, 2015). The authors also pointed out that involvement practices are investigated in most studies as an employee attitude, understood as commitment, and not as an organization's policy, which is the focus variable of this research. In addition, as an academic contribution, this study proposed the confirmatory validation of the Resilience at Work Scale (Gomide et al., 2015), which had previously only been validated with exploratory methods, and obtained good psychometric indexes, which makes it possible to perform relational studies using reliable measures and enhances their external validity and generalization. It is suggested that further research present convergent validity with other similar constructs, such as coping, which refers to the ways in which attempts are made to change or interpret circumstances in order to make them more favorable and less threatening (Lazarus \& Folkman, 1984).

As the data from this study suggested, resilience at work is a consequence of the perception of involvement policy. This consideration therefore reflects the need for a well-developed set of involvement practices insofar as they effectively influence the resilience of employees.

Social skills, supportive links that help overcome difficulties, and factors that influence resilience at work are considered elements to be developed and maintained in organizations, in order to achieve a positive impact on employees' motivation and productivity, cooperation among members, and the achievement of organizational objectives (Dutton, Dukerich, \& Harquail 1994; Fernandes \& Zanelli, 2006). In this sense, involvement practices reflect an effort by the organization to enable a healthy relationship between the subject and his or her job even in a context marked by stressors, such as the need for changes, pressure for results, among other scenarios in which resilience assumes a special connotation. The more employees perceive management efforts to involve them, the more they will tend to be resilient (Barlach, LimongiFrança, \& Malvezzi, 2008; Ribeiro et al., 2011). This result sheds light on future perspectives and studies on resilience at work, which will possibly translate into greater employee well-being and better organizational outcomes. 


\section{References}

Abbad, G., \& Torres, C. V. (2002). Regressão múltipla stepwise e hierárquica em Psicologia Organizacional: Aplicações, problemas e soluções. Estudos de Psicologia, 7 (special edition), 19-29.

Anonymous. (n.d.). A importância da resiliência em tempos de crise (Interview with Edna Bedani). Associação Brasileira de Recursos Humanos de São Paulo. Retrieved from http://abrhsp.org.br/ blog/noticias/1792-a-importancia-da-resilienciaem-tempos-de-crise

Armstrong, M. (2014). Armstrong's handbook of human resource management practice (13rd ed.). London: Kogan Page.

Badejo, A. E. (2015). Strategic human resource management practices and employees' career development in selected commercial banks in Lagos State, Nigeria. European Journal of Business and Management, 7(2), 83-94.

Barlach, L., Limongi-França, A. C., \& Malvezzi, S. (2008). O conceito de resiliência aplicado ao trabalho nas organizaçóes. Revista Interamericana de Psicologia, 42(1), 101-112.

Bastos, A. V. B. (1994). Comprometimento organizacional: Seus antecedentes em distintos setores da administração e grupos ocupacionais. Temas em Psicologia, 2(1), 73-90.

Batista, R. L. (2010). Percepção de suporte organizacional, afeto positivo, afeto negativo $e$ resiliência: Antecedentes da confiança do empregado na organização (Master Degree Dissertation). Universidade Federal de Uberlândia, Uberlândia, MG, Brasil.

Batista, R. L., \& Oliveira, A. de F. (2008). Validação da escala de resiliência para o contexto organizacional. Poster Session presented at the Congresso Brasileiro de Psicologia Organizacionale do Trabalho, Florianópolis, SC, Brasil, 3.

Batista, R. L., \& Oliveira, A. de F. (2012). Antecedentes da confiança do empregado na organização. Estudos de Psicologia, 17(2), 247-254.
Bohlander, G. W., \& Snell, S. (2009). Administração de recursos humanos (14a ed.). São Paulo: Cengage.

Boudreau, J., \& Lawler, E., III. (2014). Stubborn traditionalism in HRM: Causes and consequences. Human Resource Management Review, 24(3), 232244.

Brandão, H. P., Borges-Andrade, J. E., \& Guimarães, T. A. (2012). Desempenho organizacional e suas relações com competências gerenciais, suporte organizacional e treinamento. Revista de Administração, 47(4), 523-539.

Byrne, B. M. (2009). Structural equation modeling with AMOS: Basic concepts, applications, and programming (2nd ed.). New York: Routledge.

Carvalho, V. D., Borges, L. O., Vikan, A., \& Hjemdal, O. (2011). Resiliência e socialização organizacional entre servidores públicos brasileiros e noruegueses. Revista de Administração Contemporânea, 15(5), 815-833.

Chin, W. W. (1998). The partial least squares approach to structural equation modeling. In G. A. Marcoulides (Ed.). Modern methods for business research. Methodology for business and management (pp. 295-336). Mahwah, NJ: Lawrence Erlbaum Associates Publishers.

Cohen, J. (1992). A power primer. Psychological Bulletin, 112(1), 155-159.

Deadrick, D. L., \& Stone, D. L. (2014). Human resource management: Past, present, and future. Human Resource Management Review, 24(3), 193-195.

Demo, G. (2008). Desenvolvimento e validação da escala de percepção de políticas de gestão de pessoas (EPPGP). Revista de Administração Mackenzie, 9(6), 77-101.

Demo, G., Fogaça, N., Fernandes, T., \& Sá, P. (2015). Políticas e práticas de gestão de pessoas: Revisão bibliométrica da produção nacional em 
periódicos de primeira linha e institucionalização da pesquisa no Brasil entre 2010 e 2014 . Anais do Encontro de Gestão de Pessoas e Relaçóes de Trabalho, Salvador, BA, 5 .

Demo, G., Martins, P. R., \& Roure, P. (2013). Políticas de gestão de pessoas, comprometimento organizacional e satisfação no trabalho na Livraria Cultura. Revista Alcance, 20(2), 237-254.

Demo, G., Neiva, E. R., Nunes, I., \& Rozzett, K. (2012). Human resources management policies and practices scale (HRMPPS): Exploratory and confirmatory factor analysis. Brazilian Administration Review, 9(4), 395-420.

Demo, G., Neiva, E. R., Nunes, I., \& Rozzett, K. (2014). Políticas e práticas de recursos humanos. In M. M. M. Siqueira, (Org.), Novas Medidas do Comportamento Organizacional: Ferramentas de Diagnóstico e de Gestão (pp. 240245). Porto Alegre: Artmed.

Demo, G., Nunes, I., Mendes, N. M. D., Ferreira, L. A., \& Melo, B. B. (2011). Políticas de gestão de pessoas: Cenário dos estudos publicados nos periódicos da área de Administração. Revista Organizaçóes em Contexto (Online), 7(14), $57-$ 84. Retrieved from https://www.metodista.br/ revistas/revistas-ims/index.php/OC/article/ view/2730

Demo, G., \& Rozzett, K. (2012). Human Resource Management Policies and Practices (HRMPP): Scale validation in the United States. International Journal of Strategic Management, 12(3), 41-66.

Dessler, G. (2002). Human resource management (9th ed.). New Jersey: Prentice Hall.

Devanna, M. A., Fombrun, C. J., \& Tichy, N. M. (1984). A framework for strategic human resource management. In C. J. Fombrun, M. M. Tichy, \& M. A. Devanna (Eds.) Strategic Human Resource Management (pp. 33-51). New York: John Wiley.

Dietz, G., Wilkinson, A., \& Redman, T. (2010). Involvement and participation. In A. Wilkinson,
N. Bacon, T. Redman, \& S. Snell (Eds.). The $S A G E$ handbook of human resource management (pp. 245-268). London: Sage.

Dutton, J. E., Dukerich, J. M., \& Harquail, C. V. (1994). Organizational images and member identification. Administrative Science Quarterly, 39(2), 239-263.

Fernandes, K. R., \&Zanelli, J. C. (2006). O processo de construção e reconstrução das identidades dos indivíduos nas organizações. Revista de Administração Contemporânea, 10(1), 55-72.

Ferreira, M. C. (2016). Qualidade de vida no trabalho: Uma abordagem centrada no olhar dos trabalhadores (3a ed.). Brasília - DF: Paralelo 15.

Field, A. (2009). Descobrindo a estatística usando o SPSS. Porto Alegre: Artmed.

Figueiredo, D. B., Fo, \& Silva, J. A., Jr. (2010). Visão além do alcance: uma introdução à análise fatorial. Opinião Pública, 16(1), 160-185.

Freitas, I. A., \& Borges-Andrade, J. E. (2004). Efeitos de treinamento nos desempenhos individual e organizacional. Revista de Administração de Empresas, 44(3), 44-56.

Gomide, S., Jr., Silvestrin, L. H. B., \& Oliveira, A. de F. (2015). Bem-estar no trabalho: O impacto das satisfaçóes com os suportes organizacionais e o papel mediador da resiliência no trabalho. Revista Psicologia: Organizaçóes e Trabalho, 15(1), 19-29.

Gomide, S., Jr., \& Tanabe, T. R. (2012). Políticas de gestão de pessoas e efetividade organizacional. In G. Demo (Org.). Politicas de gestão de pessoas nas organizaçóes: Estado da arte, produção nacional, agenda de pesquisa, medidas e estudos relacionais (pp. 175-195). São Paulo: Atlas.

Guest, D., \& Conway, N. (2011). The impact of HR practices, HR effectiveness and a 'strong HR system' on organizational outcomes: A stakeholder perspective. The International Journal of Human Resource Management, 22(8), 1686-1702. 
Hackman, J. R., \& Oldham, G. R. (1976). Motivation through the design of work: Test of a theory. Organizational Behavior and Human Performance, 16(2), 250-279.

Hair, J. F. Jr., Babin, B., Money, A. H., \& Samouel, P. (2005). Fundamentos de métodos de pesquisa em administração. Porto Alegre: Bookman.

Hair, J. F., Jr., Black, W. C., Babin, B. J., Anderson, R. E., \& Tatham, R. L. (2009). Análise multivariada de dados (6a ed.). Porto Alegre: Bookman.

Hernandez, J. (2007). Impactos da percepção de saúde organizacional no bem-estar no trabalho (Master Degree Dissertation). Universidade Federal de Uberlândia, Uberlândia, MG, Brasil.

Horta, P., Demo, G., \& Roure, P. (2012). Políticas de Gestão de Pessoas, confiança e bem-estar no trabalho: Estudo em uma multinacional. Revista de Administração Contemporânea, 16(4), 566-585.

Hoyle, R. H. (1995). Structural equation modeling: Concepts, issues, and applications. Thousand Oaks, CA: Sage Publications.

Inyang, B. J., \& Akaegbu, J. B. (2014). Redefining the role of the human resource professional (HRP) in the Nigerian public service for enhanced performance. International Journal of Business Administration, 5(1), 90-98.

Jesus, R. G., \& Rowe, D. E. O. (2015). Percepção de políticas de gestão de pessoas e comprometimento organizacional: $\mathrm{O}$ papel mediador da percepção de justiça organizacional. Tourism \& Management Studies, 11(2), 211-218.

Job, F. P. P. (2003a). Os sentidos do trabalho e a importância da resiliência nas organizaçôes (Doctor Degree Thesis). Escola de Administração de Empresas de São Paulo, São Paulo, SP, Brasil.

Job, F. P. P. (2003b). Resiliência na organização: Estudo de caso da medição e avaliação da resiliência de indivíduos em uma organização industrial. Revista Faculdade de Ciências Médicas de Sorocaba, 5(1), 33-42.

Kim, A., \& Lee, C. (2012). How does HRM enhance strategic capabilities? Evidence from the Korean management consulting industry. The International Journal of Human Resource Management, 23(1), 126-146.

Kline, R. B. (2011). Principles and practice of structural equation modeling (3rd ed.). New York: The Guilford Press.

Lazarus, R. S., \& Folkman, S. (1984). Stress, appraisal, and coping. New York: Springer.

Legge, K. (1995). Human resource management: Rethorics and realities. London: Macmillan.

Leite, N., Leite, F., \& Albuquerque, L. (2013). A gestão de pessoas e as estratégias de atração, desenvolvimento e retenção de profissionais: O caso Petrobras. Revista Ibero-Americana de Estratégia, 12(4), 91-122.

Luthar, S. S., Cicchetti, B., \& Becker, B. (2000). The construct of resilience: A critical evaluation and guidelines for future work. Child Development, 71(3), 543-562.

Majumder, M. T. H. (2012). HRM practices and employees'satisfaction towards private banking sector in Bangladesh. International Review of Management and Marketing, 2(1), 52-58.

Marôco, J. (2010). Análise de equaçôes estruturais: Fundamentos teóricos, software e aplicaçóes. Lisboa: Report Number.

Martins, M., \& Demo, G. (2014). Bem-estar no trabalho na Disney: $O$ papel das políticas e práticas de gestão de pessoas. Revista Eletrônica Gestão \& Saúde, special edition, 3605-3632.

Mascarenhas, A. O., \& Kirschbaum, C. (2008). Fundamentos de gestão estratégica de pessoas. In A. O. Mascarenhas (Org). Gestão estratégica de pessoas: Evolução, teoria e crítica (pp. 23-30). São Paulo: Cengage Learning. 
Maslow, A. H. (2001). Maslow no Gerenciamento (E. Casquilho, Trad.). Rio de Janeiro: Qualitymark. (Original work published in 1965).

Mendes, A. M. (2002). Algumas contribuições teóricas do referencial psicanalítico para as pesquisas sobre organizaçóes. Estudos de Psicologia, 7 (special edition), 89-96.

Morin, E. M. (2001). Os sentidos do trabalho. Revista de Administração de Empresas, 41(3), 08-19.

Morin, E., Tonelli, M. J., \& Pliopas, A. L. V. (2007). O trabalho e seus sentidos. Psicologia \& Sociedade, 19 (special edition), 47-56.

Morris, S., \& Snell, S. (2010). The evolution of HR strategy: Adaptations to increasing global complexity. In A. Wilkinson, N. Bacon, T. Redman, S. \& Snell, (Eds.). The SAGE handbook of human resource management (pp. 84-99). London: Sage.

Muckinsky, P. M. (2004). Psicologia organizacional. São Paulo: Pioneira Thomson Learning.

Myers, R. H. (1990). Classical and modern regression with applications. Boston: PWS-Kent Publishing Company.

Nalin, C. P., \& França, L. H. F. P. (2015). A importância da resiliência para o bem-estar na aposentadoria. Paidéia, 25(61), 191-199.

Nannetti, M. A., Mesquita, J. M. C., \& Teixeira, L. A. A. (2015). A relação entre a satisfação dos funcionários e a satisfação dos clientes: estudo nas empresas de software do município de Belo Horizonte. Revista de Administração (FEA-USP), 50(1), 56-72.

Pesce, R. P., Assis, S. G., Avanci, J. Q., Santos, N. C., Malaquias, J. V., \& Carvalhaes, R. (2005). Adaptação transcultural, confiabilidade e validade da escala de resiliência. Cadernos de Saúde Pública, 21(2), 436-448.

Pesce, R. P., Assis, S. G., Santos, N., \& Oliveira, R. V. C. (2004). Risco e proteção: Em busca de um equilíbrio promotor de resiliência. Psicologia: Teoria e Pesquisa, 20(2), 135-143.

Pinheiro, D. P. N. (2004). A resiliência em discussão. Psicologia em Estudo, 9(1), 67-75.

Raykov, T., \& Marcoulides, G. A. (2006). A first course in structural equation modeling (2nd ed.). Mahwah, NJ: Lawrence Erlbaum Associates.

Ribeiro, A. C. A., Mattos, B. M., Antonelli, C. S., Canêo, L. C., \& Goulart, E., Jr. (2011). Resiliência no trabalho contemporâneo: Promoção e/ou desgaste da saúde mental. Psicologia em Estudo (Maringá), 16(4), 623-633.

Ryff, C. D., \& Singer, B. (2003). The role of emotion on pathways to positive health. In R. J. Davidson, K. R. Scherer, \& H. H. Goldsmith (Eds.). Handbook of affective sciences. New York: Oxford University Press.

Sá, P., \& Demo, G. (2014). Bem-Estar no trabalho na Fiat: $\mathrm{O}$ papel das políticas e práticas de gestão de pessoas. Revista Eletrônica Gestão \& Saúde, 5 (special edition), 3581-3604.

Santos, J. R. V. S., \& Mourão, L. (2011). Impacto do treinamento como variável preditora da satisfação com o trabalho. Revista de Administração da Universidade de São Paulo (RAUSP), 46(3), 305-318.

Sapienza, G., \& Pedromônico, M. R. M. (2005). Risco, proteção e resiliência no desenvolvimento da criança e do adolescente. Psicologia em Estudo, 10(2), 209-216.

Schumacker, R. E., \& Lomax, R. G. (2004). A beginner's guide to structural equation modeling. Mahwah, NJ: Lawrence Erlbaum Associates.

Sheehan, M. (2013). Human resource management and performance: evidence from small and medium-sized firms. International Small Business Journal, 32(5), 545-570.

Siqueira, M. M. M. (2008). Envolvimento com o trabalho. In M. M. M. Siqueira (Org.). Medidas 
do comportamento organizacional: Ferramentas de diagnóstico e de gestão (pp. 139-143). Porto Alegre: Artmed.

Siqueira, M. M. M., \& Gomide, S., Jr. (2008). Suporte no Trabalho. In Siqueira, M. M. M. (Org.). Medidas do comportamento organizacional: Ferramentas de diagnóstico e de gestão (pp. 283294). Porto Alegre: Artmed.

Sisson, K. (1994). Personnel management: Paradigms, practice and prospects. In K. Sisson (Ed.). Personnel management (2nd ed., pp. 3-50). Oxford, UK: Blackwell.
Tabachnick, B. G., \& Fidell, L. S. (2013). Using Multivariate Statistics (6th ed). Boston: Pearson.

Ulrich, D., Halbrook, R., Meder, D., Stuchlik, M., \& Thorpe, S. (1991). Employee and customer attachment: Synergies for competitive. Human Resource Planning, 14(2), 89-102.

Universidade de Brasília. (2015). Relatório de Gestão Exercício 2014. http://dpo.unb.br/ documentos/Relatorio_Gestao_2014.pdf

Yunes, M. A. M. (2003). Psicologia positiva e resiliência: $\mathrm{O}$ foco no indivíduo e na família. Psicologia em Estudo, 8 (special edition), 75-84.

\footnotetext{
About the Authors:

1. Ana Carolina Costa, Master in Management, University of Brasilia, Brasilia, Brazil.

E-mail: carolrezendecosta@gmail.com
}

ORCID

iD 0000-0003-2078-3797

2. Gisela Demo, Post Doctorate in Management \& Organizations, University of California, Los Angeles, United States of America. E-mail: giselademo@unb.br

\section{ORCID}

(iD 0000-0003-1864-0471

3. Tatiane Paschoal, PhD in Organizacional Psychology, Universidade de Brasília, Brasilia, Brazil. E-mail: tatipas@yahoo.com

ORCID

iD 0000-0002-2688-1411

\section{Contribution of each author}

\begin{tabular}{|c|c|c|c|}
\hline Contribution & Ana Carolina Costa & Gisela Demo & Tatiane Paschoal \\
\hline 1. Definition of research problem & & $\sqrt{ }$ & \\
\hline 2. Development of hypotheses or research questions (empirical studies) & & $\sqrt{ }$ & \\
\hline 3. Development of theoretical propositions (theoretical work) & $\sqrt{ }$ & & \\
\hline 4. Theoretical foundation/ Literature review & $\sqrt{ }$ & & \\
\hline 5. Definition of methodological procedures & & $\sqrt{ }$ & \\
\hline 6. Data collection & $\sqrt{ }$ & & \\
\hline 7. Statistical analysis & $\sqrt{ }$ & $\sqrt{ }$ & \\
\hline 8. Analysis and interpretation of data & $\sqrt{ }$ & $\sqrt{ }$ & $\sqrt{ }$ \\
\hline 9. Critical revision of the manuscript & & & $\sqrt{ }$ \\
\hline 10. Manuscript writing & $\sqrt{ }$ & & \\
\hline
\end{tabular}

